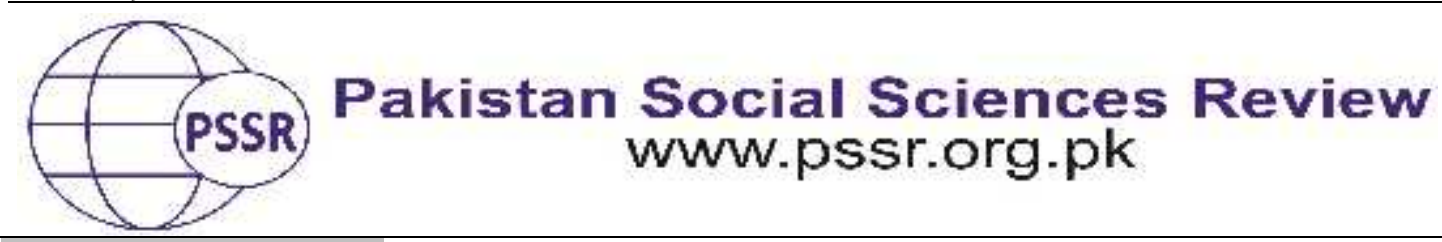

RESEARCH PAPER

\title{
"Securitization" of Islam and Muslims in the Australian Newspapers: A Critical Discourse Analysis
}

Muhammad Junaid Ghauri ${ }^{1}$ Salma Umber ${ }^{2}$ Haseeb ur Rehman Warrich ${ }^{3}$

1. Lecturer, Department of Media and Communication Studies, International Islamic University, Islamabad, Pakistan

2. Assistant Professor, Department of Mass Communication, Government College University Faisalabad, Punjab, Pakistan

3. Assistant Professor, Department of Arts and Media, Foundation University, Islamabad, Pakistan

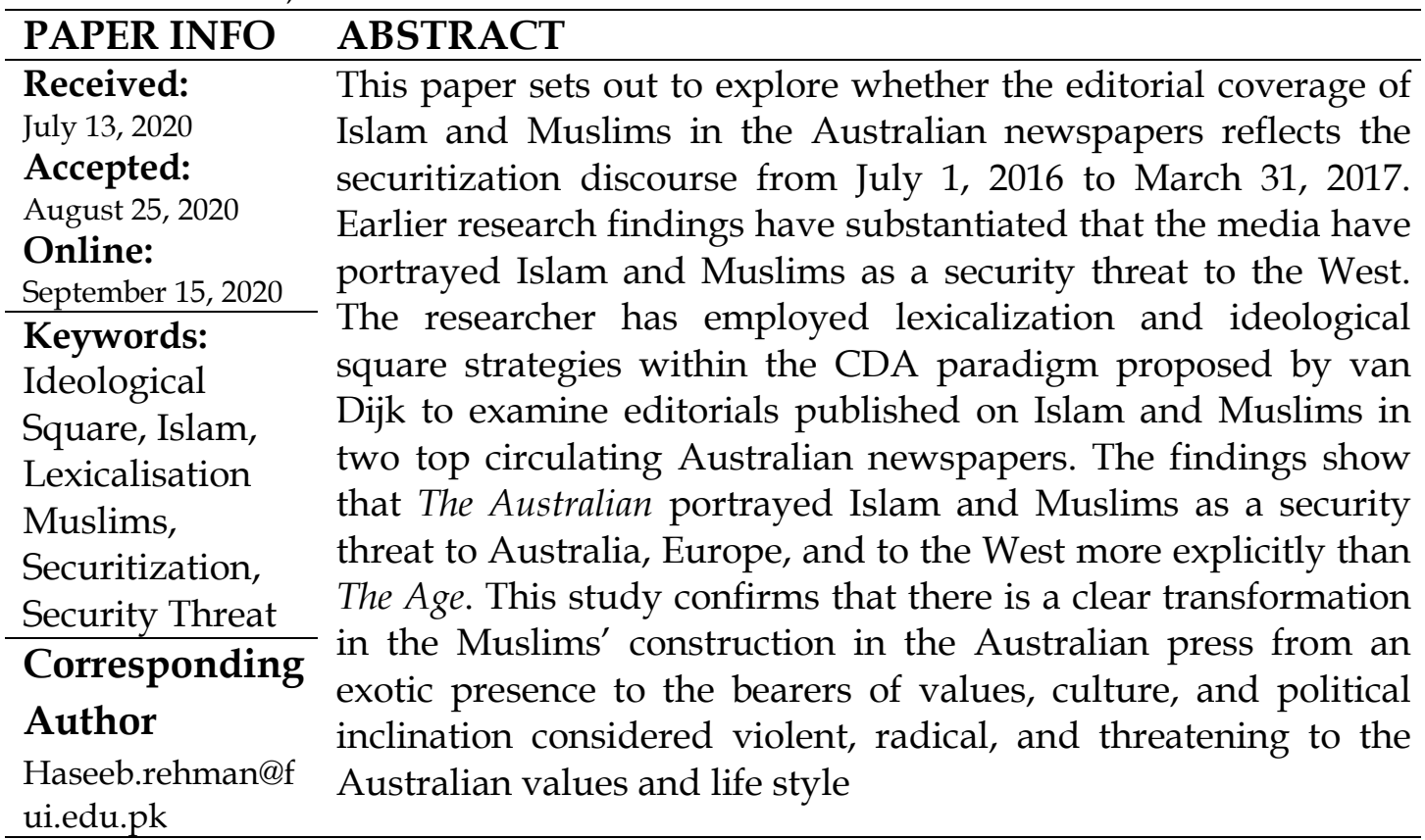

\section{Introduction}

A swift spreading out of Islam across the world led it to become a target of racial and religious discrimination. This rapid growth of Islam posed a challenge to the Western political, cultural and religious ideologies. The era of crusades further cemented hostilities and widened the racially-prejudiced view of "us" and "them" (Iqbal, 2010). Since 1990s the visibility of Islam and Muslims increased in public discourse, international media and in academic research with mostly negative implications though (Mertens \& Smaele, 2016, p. ix). However, after 9/11 the coverage of Islam and Muslims got worse to an unprecedented. Later on, the terrorist attacks like; 7/7 London bombings, Charlie Hebdo shootings, Bali attacks, Mumbai attacks, Madrid bombings, Brussels shootings, etc. brought debates about 
Islam and Muslims in global media under attention and gave unparalleled hostile coverage to Islam and Muslims in Europe (Tsagarousianou, 2016).

Similarly, Ghauri (2019; 2018a; 2018b) explored the impact of right-left ideological lines of the Australian newspapers in the editorial coverage regarding Islam and Muslims in Australia. He argued that there was a clear evidence of the "political parallelism" discourse in the Australian press wherein the left-wing newspaper The Age portrayed Islam and Muslims in a positive way while the rightwing newspaper The Australian constructed a negative image of Islam and Muslims in Australia. His studies evidenced that the leftist newspaper criticized the rightist political parties and their conservative policies towards Muslims. The Age stressed the need of "harmony", "understanding", and "cohesion". However, the right-wing newspaper, The Australian-which is a widely circulated and read newspaperopposed the leftist approach, appreciated conservative political stance towards Muslims, advocated anti-Muslim and anti-immigration policies, highlighted violence in the Muslim majority states, and portrayed a "collectivized" image of Islam and Muslims (Ghauri 2019; 2018a \& 2018b).

Tsagarousianou (2016) elaborates the "securitization" of Islam as; the gradual transformation of discourse from an "exotic Islam" to a "threatening Islam" that endangers European values and safety (Tsagarousianou 2016 in Mertens and Smaele 2016)

She argues that the incidents of political violence and terrorism have indiscriminately attached Islam and Muslims, both in and outside Europe, with irrational and uncompromising "terrorist violence". The political and terrorist violence, along with the concerns of "public safety", has paved the way of "securitization" of anything associated to Islam. Islam as a religion, its followers, Islamic communities, culture, and values are not only seen as a mere "irritating anomaly" in Europe but as a significant "societal threat". Consequently; terrorism, fundamentalism, Islamic militancy, and jihad have become a "staple vocabulary" when Islam and Muslims are discussed in Europe by politicians, policymakers, commentators, and public.

Cesari (2010) calls the securitization of Islam as a process of fearing and fostering radicalization due to the "paradoxical policy of European governments" established under the "trite depictions of Islam in professional debates". Cesari highlights conditions that lead to securitization of Islam, such as; "viewing Muslims as threat to the European survival", and Islam as an "existential threat to European political and secular norms".

Tsagarousianou (2016) in her study inspects the leading public and media discourses regarding Islam and Muslims in Spain, Netherlands, France, the UK, and Denmark. She elucidates that there is a slow but gradual change in the discourse about Islam from the "exotic Islam" to a "threatening Islam" which threatens the European way of life and the safety. She labels this change as "securitization of 
Islam" discourse (Tsagarousianou 2016, p. ix, 3). She demonstrates that within the list of large number of global terrorist incidents the killing of the Charlie Hebdo editorial team in 2015 is the last incident where the depiction of Islam and Muslims comes into view as problematic in Europe. Subsequent coverage of the murderd escribed Charlie Hebdo as a symbol of freedom and Islam as religion and the Muslims, who follow it, as an increasing threat to the value.

Cesari (2010) argues that the discourse of securitization about Islam and Muslims in Europe shapes policy making and influences the immigration rules, minority laws, and their schooling along with the broader process of inclusion. Similarly, Izadi and Saghaye-Biria argue that overall depiction of the Muslimcountries and political situations in the Muslim-world is based on the orientalist discourse wherein Islam is represented as a source of threat.

A careful review of the available relevant literature suggests that the construction and portrayal of Islam and Muslims in the media of the U.S., the UK, Australian, and in other European countries is problematic. Islam and Muslims are being represented stereotypically and as "exotic other". However, it is interesting to dig out if there is any change in the discourse regarding Islam in Muslims in the Australian press from an "exotic Islam" to a "threatening Islam". As evidenced by earlier research in other countries, it is worth knowing if the "securitization of Islam" does exist in the Australian press?

So, this paper is an attempt to dig out and identify the "securitization of Islam and Muslims" discourse in the Australian newspapers from July 1, 2016 to March 31, 2017.

The researcher has examined the editorials about Islam and Muslims published in two Australian newspapers; The Age and The Australian. The selected newspapers are considered as representative and appropriate sample of the 'Australian Press' for the intended objective because of their candid, explicit and lucid ideological lines. The Age is a national daily newspaper based in Melbourne and is being published in a compact format since 1854. This Fairfax Media owned newspaper is the $6^{\text {th }}$ most published newspapers in Australia with an explicitly leftwing or centre-left editorial policy and ideological political line (Audit Bureau of Circulations, 2017; Reimers, 2016; Ramirez, 2016; The Age, 2017). The Australian, on the other hand, is a broadsheet daily newspaper owned by News Corporation. It is based in Sydney and is being circulated since 1964. The Australian is recognized as a rightist newspaper with an explicitly right-wing editorial policy and ideological political line (Audit Bureau of Circulations, 2017; Reimers, 2016; Ramirez, 2016; The Australian, 2017).

\section{Securitization of Islam and Muslims}

"Securitization of Islam and Muslims" is the discourse that contains portrayal of Islam as "violent", "dangerous", and "threatening" to the European values and safety. Perceptions about Muslims as the followers of "an intransigent and 
increasingly aggressive Islam" and as the bearers of "political tendency", "cultural traits", and "values" that are considered as "violent", "radical", and "threatening" to the European safety, culture and values.

The editorial contents that portray Islam and Muslims as violent, dangerous, radical and threatening to The Australian safety, culture, and values is considered as the "Securitization of Islam and Muslims" discourse. Using the lenses of "lexicalization" and "ideological square" the editorial contents will be analyzed to identify the discourse.

\section{Material and Method}

\section{Data Collection and Sampling}

For this paper, the researcher selected 2 editorials from each newspaper using purposive sampling for the purpose of exploring the othering discourse in the editorial coverage of The Age and The Australian about Islam and Muslims.

Keeping in view the basic objective of this study, editorials from two highly published and candid policies bearing Australian newspapers have been analyzed usingIdeological Square and Lexicalization within the Critical Discourse Analysis (CDA) paradigm. The researcher collected data using key terms 'Islam' and 'Muslims' through 'LexisNexis' from the selected newspapers for the time period January 1, 2016 to December 31, 2016. The researcher has employed 'Census Sampling', 'Data Cleansing', and the 'Purposive Sampling' to select the most relevant editorials from the overall data. The researcher has selected two editorials as sample from each newspaper using the purposive sampling for the desired objective. The chosen editorials are component of the broader sample used in his PhD thesis by the researcher

\section{Data Analyses}

The data has been analyzed and interpreted using the ideological square and lexicalization proposed by Teun A. van Dijk (1998b) within the paradigm of Critical Discourse Analysis (CDA). The process includes identifying and exploring prominent verbs, phrases, adjectives, adverbs, and sentences within the headlines and the overall text of the editorials. The researcher has employed ideological square and lexicalization as lenses to carry out the process of data analyses and interpretation.

There is a variety of approaches and techniques of critical discourse analysis developed by its proponents and advocates based on various theoretical features and aspects (Wodak \& Meyer, 2001). However, in this study the researcher has employed a 'social cognitive perspective' proposed by Teun A. van Dijk (1993; 1995; 2000). According to this paradigm the power is exercised and maintained through manipulation of minds. There is a direct and deep social cognitive connection 
between discourse and dominance which makes it crucial to examine the production and reproduction of the texts 'critically' (van Dijk, 1993). The researcher has employed two CDA strategies to analyze the newspaper texts i.e. Ideological Square and Lexicalization.

The 'Ideological Square' approach incorporates binary positions emphasizing 'Our' good, 'Their' bad and de-emphasizing 'Their' good and 'Our' bad. This strategy, as proposed and advocated by Teun A. van Dijk (1998a \& 1998b), of positive in-group and negative out-group is manifested through various lexical choices and many other linguistic facets within a discourse (van Dijk, 1998b p. 33). So, in terms of the 'ideological square' the in-group and out-group are presented in a polarized way wherein in-group (Us) is portrayed in a positive and favorable way while out-group (Them) is portrayed in an unfavorable and negative way (Kuo \& Nakamura, 2005).

The 'ideological square' is a theoretical and methodological model that lays emphasis on media texts' examination to determine and unpack journalistic ideological positions that establish distinguishable projection and construction of various social groups (Philo, 2007). Lexicalization and polarization (Us vs. Them categorization) are two out of numerous analytical techniques within the domain of the 'ideological square' wherein the former is associated with the 'style' and the latter is related to the 'meaning' aspect of the critical discourse analysis (van Dijk, 2004).

The strategy of 'lexicalization' is incorporated through 'lexical choices' i.e. employing positive and negative evaluations within a text to portray 'Us' (in-group) favorably and 'Them (out-group) unfavorably. The lexicalization is the manifestation of the 'ideological polarization' within a discourse (Shojaei, Youssefi \& Hosseini, 2013, p. 859).

So, the researcher has employed the 'ideological square' and the 'lexicalization' from the CDA paradigm because of their relevance and suitability with the nature of this study.

\section{Results and Discussion}

\section{Analysis on The Age}

Main objective that was set at the outset of this study was to determine if there was any transformation in the Muslims' construction, in The Age and The Australian, from an "exotic presence" to the bearers of values, culture, and political inclination considered "violent", "radical", and "threatening" to the Australian security, values, and life style.

The analyzed editorial contents of The Age provide only a hint of the "securitization" discourse. The findings show that in both the editorials of The Age two terms; "Islamist terrorism" and "Islamist terror" have been used. Wearing the 
lenses of "lexicalization" and "ideological square", the researcher has found out following relevant notable themes in the editorial contents of The Age;

The editorial entitled; "PM's cowardly stance on Trump shames us all", published on January 31, 2017, was the first one in the selected sample to be studied. The editorial contained following "securitization" themes; "Islamist terrorism", "monstrous act of terrorism", "terrorist act", "atrocities", and "terrorists".

The lexical item "Islamist terrorism" gives a hint of "securitization" discourse regarding Muslims where in "they" have been portrayed as terrorists and Islam has been conflated with terrorism. However, "monstrous act of terrorism", "terrorist act", "atrocities", "terrorists", represent a counter discourse wherein terrorism has not been conflated with Islam. Also, the use of "Islamist terrorism" has been referred to Mr. Trump's speech against Muslims.

Second editorial that contained relevant discourse among the selected sample of The Age was published on July 11, 2016 titled; "Western voices must swell as IS grip slips". Following "securitization" themes were prominent in the editorial contents; "Islamic State" and "pointing to new phase in Islamist terror".

The newspaper portrays the terrorist attacks stereotypically as "Islamist terror" but at the same time uses "slaughter of civilians" for the victims. There is a hint of "securitization" discourse in terms of "Islamic terror" and "Islamic state". The recent spate of geographically diverse attacks shows IS exists not just as a physical militia claiming Iraqi and Syrian land but a force in cyberspace... (The Age July 11, 2016).

The securitization discourse does appear here for the first time in the form of such comments wherein the "threat" has been claimed to be not "limited to Middle East". So, the "Islamist terror" has been portrayed as "threatening" to "us" in these comments.

Overall, there is only a hint of "securitization" discourse in the editorial contents of The Age regarding Islam and Muslims. Only two terms i.e. "Islamic terror" and "Islamist terror" has been used to portray Islam as a "security" threat to Australia. However, dichotomy between "us" and "them" and the difference between the representation of "in-group" and "out-group" is evident in the editorial contents.

\section{Analysis on The Australian}

The analyzed editorial contents of The Australian overwhelmingly prove the transformation in the discourse regarding Islam and Muslims from "exotic" to "threatening". The findings validate that the newspaper portrayed and constructed a violent, radical and threatening image of Islam and Muslims. Wearing the lenses of "lexicalization" and "ideological square", the researcher has found out following relevant dominant themes in the editorial contents of The Australian; 
The editorial, entitled; 'Radicalisation must be resisted', published on March 4, 2017, was the first one in the selected sample to be studied. In this editorial, The Australian using 'division and rejection' strategy places 'ours' (us) in a 'multicultural' social space where 'newcomers' and 'their descendants' are accommodated. On the other hand, 'they' are placed as 'ghettos' and 'no go areas' where 'non-Muslims' are 'intimidated' and 'excluded'. Using referential terms and lexical choices, the newspaper identifies Islam and Muslims as 'exotic other' who 'intimidate' and 'exclude' non-Muslims from their 'ghettos'.

In terms of polarization strategy, $5^{\text {th }}$ paragraph of this editorial is a classic example of 'ideological square' where 'our' good and 'their' bad has been emphasized. 'Our' good has been emphasized as; ours is a coherent multicultural nation in which each wave of newcomers, and their descendants, generally, have integrated and enriched our society. On the other hand, 'their' bad has been emphasized as; That success, however, would be undone badly if encroaching sharia rendered particular areas, or schools as ghettos or no-go areas, where non-Muslims felt intimidated or excluded.

Using lexical choices such as; serious questions, exclusion of female teachers, offensive, deradicalization programs, the newspaper emphasizes 'their' bad, excludes 'them' from 'us' and present a 'misogynist' image of Islam and Muslims. The lexical items such as; Islamic militants, unleashing terror, at-risk students, present a 'securitized' discourse about 'them'. The comments such as; But at a time when Islamic militants are unleashing terror around the world... No teacher, at any school, should have to endure verbal assaults and threats of beheading or violence by any students, portray Islam and Muslims in a 'securitized' way where 'they' are portrayed as a 'security threat'.

Overall, this editorial contains 'securitization' as a predominant discourse wherein Islam and Muslims have been constructed as 'radicals', 'terrorists', and 'security threat'.

In next editorial entitled; 'Islamist terrorism re-emergent', published on December 23, 2016, the newspaper portrayed a 'securitized' image of Islam and Muslims through the themes such as;

Islamist terrorism re-emergent, The use of 'Islamist' with 'terrorism' and presupposing its 're-emergence' by The Australian makes the headline 'polarized' and 'lexical' in terms of its style. On the other hand, by conflating Islam with terrorism and by emphasizing 're-emergence' of 'Islamist terrorism', the newspaper presents a securitized, stereotypical and biased image of Islam. Overall, the headline gives an impression as if terrorism is a teaching of Islam and its reappearing. So, Islam has been portrayed as 'terrorist threat' in the editorial contents under this headline.

Lexical items used by the newspaper in next paragraph to comment on the issue represent a negative, securitized and threatening image of Islam and Muslims. The explicit use of 'the threat' from 'Islamist extremists' and emphasis on 'our doorstep' and 'our region' indicate a division of 'us' versus 'them' by the newspaper. 
The way the 'terrorist plot' has been presented as 'Islamic State-linked terrorist plot' and the use of 'Islamist' in combination with 'terrorists' identify the 'threatening' and 'securitized' image of Islam and Muslims.

In terms of polarization strategy, the 'securitization' discourse regarding Islam and Muslims is evident from the very first line of the editorial; Arrests in Indonesia and Malaysia underline the threat. While the portrayal of Islam as threat and Muslims as extremists is obvious from the comments such as; "discovery by...facing us in our region". Such comments regarding Islam and Muslims represent an 'exotic Islam to threatening Islam' image.

The lexical items used in next paragraph; conspiracy, wake-up call, The plot, suspected terrorists, Islamic State militant, portray a negative and securitized image if Islam and Muslims. The newspaper identifies 'the plot' as 'conspiracy' and warns Australian authorities (us) about the 'consequences' as; Details emerging of the new conspiracy in Indonesia, the most populous Muslim nation, are a wake-up call about the consequences if we take our eye off the ball.

In a lexical style, the newspaper portrays a securitized and negative image of Islam and Muslims. The discourse of 'securitization', wherein 'radicalization', 'fear' and 'violence' have been associated with Islam and Muslims, is obvious from the comments such as; Adding to the fundamentalist ferment is the return of hundreds of Indonesian Islamic State recruits who have been fighting in the so-called "caliphate" and are on a mission to radicalize their own country... Grave fears about violence against the Christian minority are held in relation to the trial of Ahok, with possible consequences for Indonesia's democracy.

Overall, this editorial contains 'securitization' as a predominant discourse regarding Islam and Muslims with 'Islamic Extremism', 'Islamist terrorism', 'jihadist' and 'militants' as prominent themes.

\section{Conclusion}

At the outset of this research attempt, the researcher intended to explore the existence of the discourse of "securitization" regarding Islam and Muslims in The Age and The Australian. The researcher has found out that both the dailies have produced a securitized image of Islam and Muslims in their editorial coverage. However, there is a clear distinction between the coverage of The Age and The Australian wherein the latter one has produced the "securitization" discourse regarding Islam and Muslims more explicitly as compared to the former one. The findings have validated the existence of the "securitization" discourse in the editorial contents of both the selected newspapers during the period under study. However, The Australian portrayed Islam and Muslims as a "security threat" to Australia, Europe, and to the West more explicitly than The Age. 
This study confirms that there is a clear transformation in the Muslims' construction in the Australian press from an "exotic presence to the bearers of values, culture, and political inclination considered violent, radical, and threatening to the Australian values and life style".

Drawing on the "securitization of Islam" discourse referred by Tsagarousianou (2016), Cesari (2010) and Richardson (2004), this study has found out that there is only a hint of "securitization" discourse in the editorial contents of The Age regarding Islam and Muslims. Only two terms; "Islamic terror" and "Islamist terror" were used by The Age which portrayed Islam as a "security threat" to Australia. However, The Australian hardly published any editorial, during the period under study, which did not portray Islam and Muslims as security threat to Australia, Europe and to the West.

The findings reveal that the editorial contents of The Australian contained an overtly and unambiguously "securitized" image of Islam and Muslims during the period under study. The newspaper produced "securitization" discourse containing prominent themes such as; "intimidated", "no-go areas", "Islamic militants", "unleashing terror", "at-risk students", "threats of beheading or violence", "Islamist terrorism", "the threat", "grave fears", "violence". Comparing both the newspapers, it can be concluded that The Australian portrayed Islam and Muslims overwhelmingly and explicitly as violent, radical and security threat. On the other hand, The Age used terms "Islamic terror" and "Islamist terror" portraying Islam as a security threat only in two editorials.

So, the study confirms that there is a clear transformation in Muslims' construction in the Australian press during the period under study, from an "exotic presence" to the bearers of values, culture, and political inclination considered "violent", "radical", and "threatening" to the Australian values and life style. Hence, the presence of the "securitization" discourse, the type of discourse referred by Tsagarousianou (2016) in a latest book on the topic; "Representations of Islam in the News: A cross-cultural analysis" (Mertens \& Smaele, 2016), in the Australian press regarding Islam and Muslims is confirmed. 


\section{References}

Audit Bureau of Circulations. (2017, February 25). ABC Circulation Results-Feb 2017. Retrieved February 25, 2017, from www.mumbrella.com.au: https:/ / mumbrella.com.au/abcs-weekend-nationals-grow-circulation-metroweekly-newspapers-continue-decline-427101f.

Behnam, B., \& Moshtaghi Zenouz, R. (2008). A Contrastive Critical Analysis of Iranian and British Newspaper Reports on the Iran Nuclear Power Program. Systemic Functional Linguistics in Use, Odense Working Papers in Language and Communication, 29, 199-217.

Cesari, J. (2010). Securitization of Islam in Europe . In J. Cesari, Muslim in the West after 9/11 (pp. 9-27). New York: Routledge.

Ghauri, M. J. (2018a). 'Political Parallelism' and the Representation of Islam and Muslims in the Australian Press: A Critical Discourse Analysis. International Journal of Cricis Communication, 2, 38-45.

Ghauri, M. J. (2018b). Exploring the Political Parallelism discourse on Representation of Islam and Muslims in the Australian Press. Journal of Peace Development $\mathcal{E}$ Communication, 2(2), 46-66.

Ghauri, M. J. (2019). "Political Parallelism" and the representation of Islam and Muslims in the Australian Press. SEARCH Journal of Media and Communication Research, 11(2), 21-37. Retrieved from http:/ / search.taylors.edu.my

Iqbal, Z. (2010). Islamophobia or Islamophobias: Towards Developing; A Process Model. Islamic Studies, 49(1), 81-101.

Izadi, F., \& Saghaye-Biria, H. (2007). A Discourse Analysis of Elite American Newspaper Editorials: The Case of Iran's Nuclear Program. Journal of Communication Inquiry, 31(2), 140- 165.

Koosha, M., \& Shams, M. R. (2005). A Critical Study of News Discourse: Iran's Nuclear Issue in the British Newspapers. Iranian Journal of Applied Linguistics, $8(2), 107-141$.

Kuo, S. H., \& Nakamura, M. (2005). Translation or transformation? A case study of language and ideology in the Taiwanese press. Discourse E Society, 16(3), 393-417.

Mertens, S., \& Smaele, H. D. (2016). Representations of Islam in the News: a cross-cultural analysis. Maryland-USA: Lexington Books. IX-26.

Philo, G. (2007). Can discourse analysis successfully explain the content of media and journalistic practice? Journalism Studies, 8(2), 175-196. 
Ramirez, C. (2016). Which are right-wing media and left-wing media in Australia? Retrieved October 30, 2017, from www.quora.com: https://www.quora.com/Which-are-right-wing-media-and-left-wing-media-inAustralia

Reimers, B. (2016). Which are right-wing media and left-wing media in Australia? Retrieved October 30, 2017, from www.quora.com: https://www.quora.com/Which-are-right-wing-media-and-left-wing-media-inAustralia

Richardson, J. E. (2004). (Mis)Representing Islam: The Racism and Rhetoric of British Broadsheet Newspapers. Amsterdam: John Benjamins.

Shojaei, A., Youssefi, K., \& Hosseini, H. S. (2013). A CDA Approach to the Biased Interpretation and Representation of Ideologically Conflicting Ideas in Western Printed Media. Journal of Language Teaching and Research, 4(4), 858-868.

The Age. (2017). Source Information. Retrieved December 4, 2017, from www.nexis.com:

https://www.nexis.com/results/shared/sourceInfo.do?sourceId=F_GB00NBGe nSrch.T25501762415

The Australian. (2017). Source Information. Retrieved December 4, 2017, from www.nexis.com:

https://www.nexis.com/results/shared/sourceInfo.do?sourceId=F_GB00NBGe nSrch.T26708005099

Tsagarousianou, R. (2016). Muslims in Public and Media Discourse in Western Europe: The Reproduction of Aporia and Exclusion. In S. Mertens, \& H. D. Smaele (Eds.), Representations of Islam in the News: a cross-cultural analysis (pp. 320). Maryland-USA: Lexington Books.

van Dijk, T. (1993). Principals of Critical Discourse Analysis. Discourse and Society, $4(2), 249-283$.

van Dijk, T. (1995). Discourse Analysis as Ideological Analysis. In C. Schaffine, \& A. L. Wenden, Language and peace (pp. 17-33). London: Routledge.

van Dijk, T. (1998a). Ideology A multidisciplinary approach. New York: Sage Publications.

van Dijk, T. (1998b). Opinions and Ideologies in the Press. In A. Bell, \& P. Garrett (Eds.), Approaches to Media Discourse (pp. 21-63). Oxford: Blackwell.

van Dijk, T. (2000). Ethnic Minorities and the Media, News Racism: A Discourse Analytical Approach. Buckingham: Open University Press. 
van Dijk, T. (2004). Politics, ideology and discourse. In K. B. (Ed.) (Ed.), Encyclopedia of Language and Linguistics (pp. 728-740). Oxford, UK: Elsevier.

Western voices must swell as IS grip slips. (2016, July 11). The Age, p. 16.

Wodak, R., \& Meyer, M. (Eds.). (2001). Methods of critical discourse studies. Sage. 95120. 